\title{
Neonates and Pediatrics Electrolyte Replacement Therapy Order: New Initiative and Implementation System in Saudi Arabia
}

\begin{abstract}
Yousef Ahmed Alomi* iD, The
Former General Manager of General Administration of Pharmaceutical Care, The

Former Head, National Clinical pharmacy and pharmacy practice, The Former Head, Pharmacy R\&D Administration, Ministry of Health, Riyadh, SAUDI ARABIA.
\end{abstract}

Fatimah Al-Doughan, College of Pharmacy, Pharmacy Practice Department, King Faisal University Alahssa, SAUDI ARABIA. Yasir Ahmed Ibrahim, Head of Pharmacy Practice Department, Pharmacy Practice Department, College of Clinical Pharmacy, King Faisal University, Alahssa, SAUDI ARABIA.

Hussam Saad Almalki, Supervisor of IV Admixture Services, Aleman Hospital, Ministry of Health, Riyadh, Riyadh, SAUDI ARABIA.

Nouf Alaza, Director of Medication Safety Officer, Pharmacy Services, Alyammama Hospital Ministry of Health, Riyadh, SAUDI ARABIA

Malika Alshamari, Head, Pharmacy services, Alyamma Hospital, Ministry of Health, Riyadh, SAUDI ARABIA.

\section{Correspondence:}

Dr. Yousef Ahmed Alomi, The Former General Manager of General Administration of Pharmaceutical Care, The Former Head, National Clinical pharmacy and pharmacy practice, The Former Head, Pharmacy R\&D Administration, Ministry of Health, Riyadh, Saudi Arabia.

Phone no: +966 504417712

E-mail:yalomi@gmail.com

\section{Received: 19-02-2019;}

Accepted: 04-05-2019

Copyright: (๑) the author(s), publisher and licensee International Journal of Pharmacology and Clinical Sciences. This is an open-access article distributed under the terms of the Creative Commons Attribution Non-Commercial License, which permits unrestricted non-commercial use, distribution, and reproduction in any medium, provided the original work is properly cited.

This is an open access article distributed under the terms of the Creative Commons Attribution-NonCommercial-ShareAlike 4.0 License

Access this article online

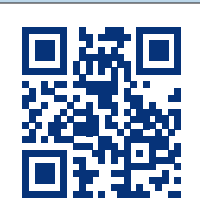

www.ijpcs.net

DOI:

10.5530/ijpcs.2019.8.47

\begin{abstract}
The national medications safety program founded in 2013 at the Ministry of Health hospitals and primary care centers in the Kingdom of Saudi Arabia. The program focused on adults, pediatrics and neonatal populations. The program was part of the pharmacy strategic plan. The electrolyte replacement therapy preparation and administration for neonates and pediatrics published and distributed as required of the medication safety program. The new initiatives as complementary project was a standardized concentration of electrolyte replacement therapy for neonates and pediatrics implemented at specific hospitals of the Ministry of health. The new project as regular physician's order form and coveted to computerized physician order entry. The new project prevents neonates and pediatrics medication errors of electrolyte replacement therapy. The project is a new initiative at Ministry of Health hospitals in the Kingdom of Saudi, Gulf and Middle East countries.

Keywords: Neonates, Pediatrics, Standardized Concentration, Electrolyte, Ministry of Health, Saudi Arabia.
\end{abstract}

\section{INTRODUCTION}

The general administration of pharmaceutical care established the national intravenous admixture program established in 2013 among part of pharmacy practice system and among pharmacy strategic plan at the Ministry of Health in the Kingdom of Saudi Arabia. ${ }^{[1,2]}$ The program takes care of adults, pediatrics and neonatal patients. The program formulated a central committee of IV drug therapy at Ministry of Health (MOH) and peripheral committees in each region. Those committed responsible for implementation of all intravenous regulars and chemotherapy medications. The central published several booklets of the standardized concentration of intravenous medications for pediatrics and neonates with the emphasis on high alert medication including the Electrolyte. ${ }^{[3,4]}$ The national accreditation organization Saudi Center for Healthcare Accreditation CBAHI and International hospital accreditation Joint Commission of hospital accreditation in the USA and the Institution of Safe Medications Practice (ISMP) considered electrolyte as high alert medication. ${ }^{[5-8]}$ All healthcare organizations should establish a system for prescribing, preparation, dispensing and administration to follow up the medications. New initiatives project on medication safety established by three hospitals in Riyadh city, Saudi Arabia Bu name neonatal and pediatrics standardized concentration physicians order form. The author is not familiar with any publications in Saudi Arabia or Gulf and Middle East counties described neonates and pediatrics electrolyte replacement therapy order.

\section{Neonates and Pediatrics Electrolyte Replacement in Saudi Arabia}

It is a standardized formulation of electrolyte requirements for neonates and pediatrics. The formulation derived from current literature and American Society for Parenteral and Enteral Nutrition (ASPEN) guidelines for neonates and pediatrics' population with an average of seventy-kilogram body weight. ${ }^{9}$ The electrolyte consisted of potassium, magnesium, calcium and phosphate. The physician order form consisted of several parts' demographic data of the patients, the laboratory level for each element of the electrolyte, the standardized concentration and maximum concentration, the type of crystallized fluid, the administration type through a central or peripheral vein, the dosing range requirements as explored in physician order entry form (Figure 1).

\section{SWOT Analysis}

The benefit and risk analysis of the project by using the SWOT (Strength, Weakness, Opportunities and Threads). The strength of the project which included the neonates and pediatrics physician order forms including all information of common electrolyte is available, dosing of medications is available, fixed standardized concentration of the electrolyte is available, the method of electrolyte administration is available and prevent mistakes in writing electrolyte orders for adults. The weakness points are including the formulation is not individualized for all patients, it cannot apply to several disease renal or hepatic failure. The opportunity that is including it is an elementary form to convert them into computerized and physician order entry, it can calculate all electrolyte statistical information. The threat point was including the physician or pharmacist is not used the standardized concentration of the electrolyte. 


\section{Implementations Steps of Electrolyte Standardized Concentration for Neonates and Pediatrics}

The pharmacy department Organize Consultation Committee from expert pharmacist especially from intravenous admixture and clinical pharmacists in neonates and pediatric critical care or total parenteral nutrition clinical pharmacist inside the pharmacy department. The committee should extensively review then approve the standardized concentration form of neonates and pediatrics electrolyte replacement form. The head of the committee will contact with neonates, pediatric surgical and medical department for final revisions of the drafting and approval. The head of pharmacy services will submit the final draft of the formulation to pharmacy and therapeutic committee for review and approval. The head of the committee will arrange with computer department to make an electronic order form. The pharmacy education coordinator arrange with all department including nursing, surgical and medical department to educate and train the medical staff of using the formulation with additional to pharmacy staff. The pharmacy quality management will set up the Key Performance Indicators (KPI) to measure the impact of the project. All pharmacy concern team including electrolyte preparation, clinical pharmacist will collect the KPI of the project retrospectively in the past three to six months. Then collect the data prospectively in the coming months. The head of the committee will contact with nursing and medical development to start with one medical department as the pilot trial. The pharmacist will review the pilot trial and correct the form according to the pharmacy consultation committee. The team will expand to all medical department and surgical department, review and alter the shape accordingly through committee. The head of the committee will expand to all hospital department including adult's critical care, review and adjust the formulation accordingly. The pharmacy quality management coordinators will measure the impact of the project by comparing the KPI before and after starting the project. The head of the committee will analyze the results and review by the consultation committee. The head of the pharmacy will submit the final report to pharmacy and therapeutic committee for final touch and comments. The consultation team review the last comments on the project, update it accordingly and continue the project with next year.

\section{CONCLUSION}

The neonatal and pediatrics standardized concentration of electrolyte replacement therapy is new initiative project in Kingdom of Saudi Arabia, Gulf and Middle East counties. The new system has potential and easy to implement. It prevents an electrolyte related adverse event and reduced economic burden of healthcare system at the Ministry of Health organizations in the Kingdom of Saudi Arabia.

\section{ACKNOWLEDGEMENT}

None.

\section{CONFLICT OF INTEREST}

The authors declare that there are no conflicts of interest.

\section{ABBREVIATIONS}

KSA: Kingdom of Saudi Arabia; MOH: Ministry of Health; CBAHI: Saudi Central Board for Accreditation of Healthcare Institutions;
ISMP: Institute of Safe Medication Practice SWOT: Strengths, Weaknesses, Opportunities and Threats; KPIs: Key Performance Indicators.

\section{ORCID ID}

Yousef Ahmed Alomi (iD https://orcid. org/0000-0003-1381-628X

\section{REFERENCES}

1. Alomi YA. National Pharmacy Practice Programs at Ministry of Health in Saudi Arabia. J Pharm Pharm Scien. 2015;1(2):17-8.

2. Alomi YA. National Intravenous (IV) Therapy Program at $\mathrm{MOH}$ in Saudi Arabia. EC Pharm Sci. 2016:2(3):307-11.

3. Alomi Y. Pediatrics Parenteral Dilution Manual. $1^{\text {st }}$ Edition. General Adminstration of Pharmaceutical care, MOH, Saudi Arabia. 2015. Available from: https://www.researchgate.net/publication/281710402_Pediatrics_Parenteral_Dilution_ Manual.

4. Alomi Y. Neonates Parenteral Dilution Manual. $1^{\text {st }}$ Edition. General Adminstration of Pharmaceutical care, $\mathrm{MOH}$, Saudi Arabia. 2015. Available from: https://www.researchgate.net/publication/281710411_Neonates_Parenteral_Dilution_ Manual.

5. The Joint Commission. Comprehensive Accreditation Manuals. Joint Commission Resources. 2019. Available from: http://www.jcrinc.com/ store/publications/manuals/.

6. Medication Management (MM). In: National Hospital Standards. 2nd Edition. Saudi Central Board for Accreditation of Healthcare Institutions 2015;194-211. Available from: http://www.cbahi. gov.sa.

7. Medication Safety Self Assessment ${ }^{\circledast}$ for HighAlert Medications. Institute for Safe Medication Practices, 2018. Available from: https://www. ismp.org/assessments/high-alert-medications.

8. Medication Safety Self Assessment for Hospitals. Institute for Safe Medication Practices - Key Definitions. 2011, pp.1-4. Available from: http://ismp. org/selfassessments/Hospital/2011/definitions. pdf.

9. Jacobs DO Helton $S$ et.al. Guidelines for the Use of Parenteral and Enteral Nutrition in Adult and Pediatric Patients. J Parenter Enter Nutr. 2002:26(1Suppl):1SA-138SA. 
KINGDOM OF SAUDI ARABIA

Figure 1

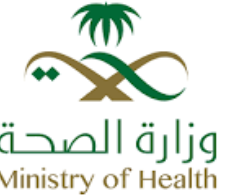

Hospital:

Region:

Dept./Unit: القسم/الوحدة:
MRN:

Name:

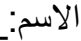

Nationality: الجنسية

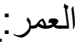

Gender:

\section{الطبي: - - الطي}

رقم الملف

Gender:

Male

Female

\section{Electrolyte Replacement Therapy Form For NICU(1)(2)(3)(4)(5)}

\begin{tabular}{|l|l|l}
\hline Diagnosis Allergy: & Weight & Height: \\
\hline \multicolumn{2}{|c|}{ BSA: } & Start Date: \\
\hline Level &
\end{tabular}

\begin{tabular}{l|l|l|l|l|l}
\hline Level & Standard Formula & Freq. & Disp. & Rate Of Infusion & Dose \\
\hline
\end{tabular}

\section{Potassium Chloride ( $2 \mathrm{mmol} / \mathrm{ml}$ ) - Peripheral line}

\begin{tabular}{|c|c|c|c|c|}
\hline \multirow{5}{*}{$\begin{array}{c}3.1-3.4 \\
\mathrm{mEq} / \mathrm{L}\end{array}$} & & \multirow{5}{*}{$\begin{array}{l}\text { IV infusion over } \\
20 \text { hours } \\
(5 \mathrm{mmol} / \mathrm{hr})\end{array}$} & \multirow{4}{*}{\multicolumn{2}{|c|}{$\begin{array}{l}\text { Parenteral Replacement therapy } \\
\text { Oral therapy preferred in mild to moderate } \\
\text { deficiency; if the patient can't ingest orally } \\
\text { should be started on parenteral therapy }\end{array}$}} \\
\hline & $0.5 \mathrm{ml} / 5 \mathrm{ml} \mathrm{D} 5 \mathrm{~W}$ & & & \\
\hline & $0.25 \mathrm{ml} / 2.5 \mathrm{ml} \mathrm{D5W}$ & & & \\
\hline & $0.5 \mathrm{ml} / 5 \mathrm{ml} \mathrm{NS}$ & & & \\
\hline & $0.25 \mathrm{ml} / 2.5 \mathrm{ml} \mathrm{NS}$ & & \multicolumn{2}{|r|}{ Serum $\mathrm{K+}$} \\
\hline \multirow{4}{*}{$\begin{array}{l}2.6-3 \\
\mathrm{mEq} / \mathrm{L}\end{array}$} & $0.5 \mathrm{ml} / 5 \mathrm{ml} \mathrm{D} 5 \mathrm{~W}$ & \multirow{4}{*}{$\begin{array}{l}\text { IV infusion over } \\
15 \text { hours } \\
(7.5 \mathrm{mmol} / \mathrm{hr})\end{array}$} & $>3.5 \mathrm{mEq} / \mathrm{L}$ & None \\
\hline & $0.25 \mathrm{ml} / 2.5 \mathrm{ml} \mathrm{D5W}$ & & $3.1-3.4$ & \multirow{2}{*}{$\begin{array}{l}\text { single dose of } 20-40 \mathrm{mmol} \\
\text { by IV infusion over } 6-8 \mathrm{hrs}\end{array}$} \\
\hline & $0.5 \mathrm{ml} / 5 \mathrm{ml} \mathrm{NS}$ & & $\mathrm{mEq} / \mathrm{L}$ & \\
\hline & $0.25 \mathrm{ml} / 2.5 \mathrm{ml} \mathrm{NS}$ & & $2.6-3 \mathrm{mEq} / \mathrm{L}$ & $\begin{array}{l}\text { single dose of } 20-40 \mathrm{mmol} \\
\text { by IV infusion over } 6-8 \mathrm{hrs}\end{array}$ \\
\hline \multirow{4}{*}{$\begin{array}{l}\leq 2.5 \\
\mathrm{mEq} / \mathrm{L}\end{array}$} & $0.5 \mathrm{ml} / 5 \mathrm{ml} \mathrm{D5W}$ & \multirow{4}{*}{$\begin{array}{l}\text { IV infusion over } \\
10 \text { hours } \\
(10 \mathrm{mmol} / \mathrm{hr})\end{array}$} & $\leq 2.5 \mathrm{mEq} / \mathrm{L}$ & 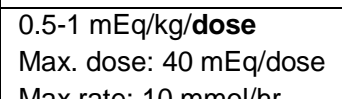 \\
\hline & $0.25 \mathrm{ml} / 2.5 \mathrm{ml} \mathrm{D5W}$ & & \multirow{2}{*}{$\begin{array}{c}\text { Daily } \\
\text { requirement }\end{array}$} & \multirow{2}{*}{2 to $4 \mathrm{mEq} / \mathrm{kg} / \mathrm{day}$} \\
\hline & $0.5 \mathrm{ml} / 5 \mathrm{ml} \mathrm{NS}$ & & & \\
\hline & $0.25 \mathrm{ml} / 2.5 \mathrm{ml} \mathrm{NS}$ & & & \\
\hline \multicolumn{5}{|c|}{ Magnesium Sulphate ( $0.4 \mathrm{mmol} / \mathrm{ml}$ ) - Peripheral line } \\
\hline \multirow{4}{*}{$<1.5$} & $1 \mathrm{ml} / 5 \mathrm{ml} \mathrm{D} 5 \mathrm{~W}$ & \multirow{4}{*}{$\begin{array}{c}\text { IV infusion over } \\
4 \text { hours }\end{array}$} & \multicolumn{2}{|c|}{ Serum $\mathrm{Mg++}$} \\
\hline & $0.5 \mathrm{ml} / 2.5 \mathrm{ml} \mathrm{D5W}$ & & $\geq 2 \mathrm{mEq} / \mathrm{L}$ & None \\
\hline & $1 \mathrm{ml} / 5 \mathrm{ml} \mathrm{NS}$ & & \multirow{2}{*}{$<1.5 \mathrm{mEq} / \mathrm{L}$} & \multirow{2}{*}{$\begin{array}{l}0.2 \mathrm{mmol} / \mathrm{Kg} / \mathrm{dose} \\
\text { Max. dose: } \\
8 \mathrm{mmol} / \text { dose }\end{array}$} \\
\hline & $0.5 \mathrm{ml} / 2.5 \mathrm{ml} \mathrm{NS}$ & & & \\
\hline & \multicolumn{4}{|c|}{ Calcium Gluconate ( $0.23 \mathrm{mmol} / \mathrm{ml}$ ) - Peripheral line } \\
\hline \multirow{7}{*}{$<4.5$} & $0.5 \mathrm{ml} / 5 \mathrm{ml} \mathrm{D} 5 \mathrm{~W}$ & \multirow{7}{*}{$\begin{array}{l}\text { Slow IV over 5-10 min, may } \\
\text { repeat or follow with } \\
\text { Continuous Infusion } 500 \text { to } \\
800 \mathrm{mg} / \mathrm{kg} / \mathrm{day}\end{array}$} & \multicolumn{2}{|r|}{ Serum $\mathrm{Ca}++$} \\
\hline & $0.25 \mathrm{ml} / 2.5 \mathrm{ml} \mathrm{D5W}$ & & \multicolumn{2}{|r|}{ None } \\
\hline & \multirow{5}{*}{$0.5 \mathrm{ml} / 5 \mathrm{ml} \mathrm{NS}$} & & \begin{tabular}{|l|l}
$<4.5 \mathrm{mg} / \mathrm{dl}$ \\
Asymptomatic
\end{tabular} & $\begin{array}{l}30 \text { to } 60 \mathrm{mg} / \mathrm{kg} / \text { dose } \\
\text { calcium salt }\end{array}$ \\
\hline & & & Symptomatic & $\begin{array}{l}100 \text { to } 200 \mathrm{mg} / \mathrm{kg} / \mathrm{dose} \\
\text { calcium salt }\end{array}$ \\
\hline & & & Cardiac arrest & 60 to $100 \mathrm{mg} / \mathrm{kg} / \mathrm{dose}$ \\
\hline & & & \begin{tabular}{|l|l|} 
Maintenance \\
Daily
\end{tabular} & 200 to $800 \mathrm{mg} / \mathrm{kg} / \mathrm{day}$ \\
\hline & & & \begin{tabular}{|l|l} 
Daily \\
requirement
\end{tabular} & 0.5 to $4 \mathrm{mEq} / \mathrm{kg} / \mathrm{day}$ \\
\hline
\end{tabular}

References

1. Micromedex Solution App. IBM Corporation; 2018

Alomi YA, et al. Adults Parenteral Dilution Manual. 1st Editio. General Adminstration of Pharmaceutical Care - Ministery of Health; 2015.

Owen P, Monahan MF, MacLaren R. Implementing and assessing an evidence-based electrolyte dosing order form in the medical ICU. Intensive Crit Care Nurs.

2008;24(1):8-19.

Lexicomp® Mobile Apps. Clinical Drug Information [Internet]. 2019 [cited 2019 Jan 28]. Available from: https://online.lexi.com/lco/action/home

Injectable Drugs Guide. Vol. 27, Journal of Pharmacy Technology. 2013. 242-243 